\title{
Pendampingan Hukum \\ Terhadap Pelaku Tindak Pidana Pencurian Dengan Kekerasan Yang Dilakukan Oleh Kelompok Rentan
}

\author{
Nuriyanto $^{1}$, Suwarno Abadi ${ }^{2}$, Rihantoro Bayu Aji ${ }^{3}$ \\ 1,2,3 Fakultas Hukum, Universitas Wijaya Putra nuryantoadaim@uwp.ac.id,
}

suwarnoabadi@uwp.ac.id, bayuaji@uwp.ac.id

\begin{abstract}
Abstrak
Asas praduga tak bersalah adalah salah satu asas yang terdapat dalam hukum acara pidana di mana dalam asas ini setiap orang yang disangka, ditangkap, ditahan, dituntut dan atau dihadapkan di muka sidang pengadilan, wajib dianggap tidak bersalah sampai adanya putusan pengadilan yang menyatakan kesalahannya dan memperoleh kekuatan hukum tetap. Namun asas ini tidak mudah untuk diterapkan, terutama dalam kasuskasus pidana yang dilakukan oleh kelompok rentan. Dalam tindak pidana pencurian dengan kekerasan yang dilakukan oleh kelompok rentan seringkali mengabaikan hakhak hukum yang mereka miliki yang disebabkan oleh para pelaku tidak merasa bersalah, tidak adanya biaya untuk menyewa pengacara dan minimnya akses pengetahuan untuk mendapatkan bantuan hukum secara gratis. Berdasarkan hal tersebut, kami melakukan kegiatan pengabdian kepada masyarakat dalam bentuk pendampingan hukum kepada pelaku tidak pidana pencurian dengan kekerasan dimaksud di Pengadilan Negeri Lumajang, Jawa Timur. Tujuan dari program pendampingan ini yang pertama adalah memberikan bantuan hukum kepada kelompok rentan yang sedang menghadapi kasus hukum, kedua untuk menganalisis secara mendalam permasalahan praktek penegakan hukum bagi pelaku tindak pidana kelompok rentan. Metode yang digunakan adalah memberikan bantuan hukum dan melakukan pendampingan hukum. Hasil yang dicapai dalam pendampingan ini adalah sanksi pidana yang diterima oleh pelaku tindak pidana pencurian dengan kekerasan adalah lebih ringan 1 (satu) tahun penjara dari tuntutan jaksa penuntut umum.

Kata Kunci: Pendampingan Hukum, Kelompok Rentan, Tindak Pidana Pencurian Dengan Kekerasan, Bantuan Hukum Gratis
\end{abstract}




\section{PENDAHULUAN}

Pendampingan dan bantuan hukum yang diberikan kepada kelompok rentan atau kelompok masyarakat yang kurang atau tidak mampu ini diselenggarakan dengan melakukan pendampingan perkara, baik perkara pidana maupun perkara perdata. Selain itu pendampingan hukum ini juga dapat diberikan di dalam pengadilan maupun di luar pengadilan. Dalam perkembangannya pendampingan bantuan hukum ini tidak hanya perkara pidana atau perdata tetapi juga perkara-perkara di Pengadilan Tata Usaha Negara (Afifah 2020).

Tetapi dalam praktek perkara yang seringkali dilakukan pendampingan dan bantuan hukum oleh Lembaga Konsultasi dan Bantuan Hukum Universitas Wijaya Putra (LKBH-UWP) adalah perkara-perkara pidana, terutama yang sedang dihadapi oleh masyarakat tidak mampu (rentan).

Dalam pendampingan hukum perkara pidana Kitab Undang Undang Hukum Acara Pidana (KUHAP) telah mengatur perlindungan terhadap keluhuran harkat serta maratabat manusia, perlindungan ini berlaku mulai dari proses pemeriksaan awal sampai dengan waktu persidangan di pengadilan. Untuk menjalankan ketentuan yang terdapat dalam KUHAP terdapat asas-asas hukum yang wajib dilaksanakan oleh aparat penegak hukum, di antaranya merupakan ungkapan hukum yang bersifat generalis. Asas hukum ini sebagian bersumber dari keyakinan hukum dan norma kesusilaan.

Salah satu asas hukum dalam hukum acara pidana tersebut adalah asas praduga tidak bersalah (presumtion of innocence), asas ini menganggap bahwa setiap orang yang disangka, ditangkap, ditahan, dituntut dan atau dihadapkan dimuka sidang pengadilan senantiasa diperlakukan dan dianggap tidak bersalah sampai adanya putusan pengadilan yang menyatakan kesalahannya.

Dalam KUHAP asas praduga tak bersalah ini dijelaskan dalam Penjelasan Umum KUHAP butir ke 3 huruf c yaitu :

Setiap orang yang disangka, ditangkap, ditahan, dituntut dan atau dihadapkan di muka sidang pengadilan, wajib dianggap tidak bersalah sampai adanya putusan pengadilan yang menyatakan kesalahannya dan memperoleh kekuatan hukum tetap.

Sedangkan dalam Undang-Undang Kekuasaan Kehakiman Nomor 48 Tahun 2009, asas praduga tak bersalah diatur dalam Pasal 8 ayat (1), yang menetukan bahwa:

Setiap orang yang disangka, ditangkap, ditahan, dituntut, atau dihadapkan di depan pengadilan wajib dianggap tidak bersalah sebelum ada putusan pengadilan yang menyatakan kesalahannya dan telah memperoleh kekuatan hukum tetap.

Berlandaskan asas inilah kami dari LKBH-UWP melakukan pendampingan hukum terhadap kelompok rentan pelaku tindak pidana pencurian dengan kekerasan di wilayah hukum Kabupaten Lumajang. Pendampingan hukum ini dilakukan setelah Tim dari LKBH-UWP melakukan penelusuran awal terhadap kronologis terjadinya tindak pidana sekaligus fakta-fakta di lapangan yang dialami oleh para pelaku tindak pidana pada waktu itu.

Terdapat beberapa hal yang melatar belakangi LKBH-UWP memutuskan untuk mendampingi para pelaku tindak pidana pencurian dengan kekerasan tersebut:

Pertama, diduga terdapat pelanggaran prosedur yang dilakukan oleh aparat penegak hukum dalam proses penangkapan dan penahanan tersangka yang tidak sesuai dengan peraturan perundang undangan.

Kedua, para pelaku tindak pidana adalah dari kalangan kelompok rentan. Kelompok rentan dimaksud adalah kelompok yang kesulitan terhadap akses yudisial, kemiskinan, lack of information, buta hukum dan masih banyak lainnya (Afifah 2020).

Sebagai negara hukum yang menjunjung tinggi hak asasi manusia dengan tujuan terciptanya ketertiban umum dan demokrasi, konsekuensi logisnya, aparat penegak hukum, dalam hal ini adalah polisi, penuntut umum, hakim, pengacara, lembaga pemasyarakatan harus melaksanakan tugas dan kewajibannya berdasarkan undang-undang dan menjunjung tinggi hak asasi manusia, terhadap pencari keadilan (justibelen) demi tercapainya keadilan Ekonomi, Sosial, dan Budaya 1433 
yang hakiki (Nurhayati 2021).

Pada umumnya, dalam sistem peradilan pidana Indonesia yang secara normatif diatur dalam Undang-Undang Nomor 8 Tahun 1981 tentang Hukum Acara Pidana (KUHAP) dan undang-undang lainnya seperti Undang-Undang Kekuasaan Kehakiman, Undang-Undang Kepolisian, dan masih banyak lagi peraturan perundang-undangan lainnya. Penerapan hak azasi manusia (HAM) dalam sistem peradilan pidana telah menjadi salah satu isu penting dalam mencapai keadilan tertinggi, karena hubungan langsungnya terhadap hak-hak tersangka dan terdakwa yang harus dilindungi sehubungan dengan perlakuan hukum oleh aparat penegak hukum dalam melakukan tindakan paksaan (Rukmini 2003).

Dalam KUHAP menetapkan sepuluh prinsip tentang ketentuan Hak Asasi Manusia. Prinsip-prinsip tersebut di antaranya adalah habeas corpus, mekanisme pemulihan yang memungkinkan seseorang untuk melaporkan penangkapan atau penahanan yang melanggar hukum kepada sebuah pengadilan dan meminta agar pengadilan itu meninjau apakah penahanan itu sesuai dengan hukum atau tidak. Jika penahanan atau penahanan tersebut terbukti melanggar hukum, maka orang itu harus dilepas(Larson 2018), hak untuk diam (the right to silence), prinsip prinsip tidak menyalahkan diri sendiri (the principle of non self-incrimination), adanya batas waktu penangkapan dan penahanan, kompensasi dan rehabilitasi serta prinsip Miranda Rules dimana tiada seorangpun diharuskan menjawab untuk suatu tindak pidana umum atau tindak pidana yang belum dikenal, tanpa penjelasan dakwaan dari Jaksa Penuntut Umum, kecuali untuk kasus yang timbul di lingkungan militer, ketika sedang bertugas dalam perang atau bahaya umum, juga tidak seorangpun menjadi terdakwa dan didakwa dua kali untuk kasus yang sama (nebis in idem) sehingga membahayakan hidupnya, juga tidak akan dipaksa dalam setiap kasus pidana untuk menjadi saksi melawan dirinya sendiri (saksi mahkota), juga tidak akan dikurangi hak kehidupan, kebebasan, atau harta bendanya, tanpa proses hukum, juga kepemilikan pribadi tidak akan diambil untuk kepentingan umum, tanpa kompensasi yang adil (Hadi 2012).
Dalam kasus tindak pidana pencurian
dengan kekerasan yang dilakukan oleh kelompok rentan di Kabupaten Lumajang, seringkali tersangka mengabaikan hak-hak hukum yang mereka miliki yang disebabkan oleh tersangka tidak merasa bersalah, tidak adanya biaya untuk menyewa pengacara dan minimnya akses pengetahuan untuk mendapatkan bantuan hukum secara gratis.

\section{METODE}

Pelaksanaan pendampingan hukum ini dilakukan sejak ditandatanganinya surat kuasa khusus pada tanggal 10 Desember 2019 sampai dengan bulan Agustus 2020. Sedangkan metode yang digunakan dalam melaksanakan kegiatan pengabdian pada masyarakat ini adalah memberikan bantuan hukum dan melaksanakan pendampingan hukum. Bantuan hukum dan pendampingan hukum ini dilakukan terhadap perkara pidana Nomor 270/Pid.B/2019/PN Lmj dalam kasus tindak pidana pencurian dengan kekerasan.

Pendampingan hukum terhadap para tersangka dalam perkara diatas dilaksanakan dalam proses persidangan. Proses persidangan ini terdiri dari persidangan pada pengadilan tingkat pertama (PN Lumajang), kemudian pendampingan hukum pada pengadilan tingi dalam upaya banding dan pendampingan hukum pada tingkat kasasi di Mahkamah Agung Republik Indonesia.

\section{HASIL DAN PEMBAHASAN}

\section{Pengabaian Hak Hukum Kelompok Rentan}

Keadilan sosial bagi seluruh rakyat Indonesia, telah menjadi kesepakatan umum bangsa Indonesia yang tertuang dalam naskah Pancasila dan juga tercantum pula dalam Pembukaan Undang-Undang Dasar 1945 paragraf ke-empat, yang menjadi landasan konstitusional dalam penyelenggaraan negara dan pemerintahan di Indonesia. Konsep keadilan sosial sebenarnya tidak dapat dilepaskan dari budaya bangsa Indonesia sebagai bangsa yang sangat teguh dalam menjalankan agama dan

Ekonomi, Sosial, dan Budaya | 1434 
keyakinan terhadap Tuhan Yang Maha Esa (religious).

Membicarakan hubungan antara hukum dan keadilan, kebanyakan ahli mengidentikkan hukum dianggap sama dengan keadilan. Hal ini yang menjadi dasar argumentasi teori keadilan bermartabat, yang pada dasarnya hakikat hukum, sama dengan hakikat keadilan. Keadilan adalah tujuan yang hendak dicapai oleh setiap sistem hukum. Keadilan yang hendak diacapai adalah keadilan ekonomi, yang hanya bersifat kebendaan (materialistik), sehingga pandangan ini sangat ulititarian (Prasetyo 2015).

Keadilan sosial dalam negara hukum Pancasila mempunyai makna bahwa pendistribusian sumber daya ditujukan untuk menciptakan kesejahteraan sosial terutama bagi kelompok masyarakat terbawah atau masyarakat yang lemah sosial ekonominya, dalam hal ini disebut masyarakat rentan. Selain itu, keadilan sosial juga menghendaki upaya pemerataan sumber daya agar kelompok masyarakat yang rentan dapat segera dientaskan dan agar kesenjangan sosial ekonomi di tengah-tengah masyarakat dapat dikurangi. Dengan demikian, distribusi sumber daya yang ada dapat dikatakan adil secara sosial jika dapat meningkatkan kehidupan sosial ekonomi kelompok yang miskin sehingga tingkat kesenjangan sosial ekonomi antar kelompok masyarakat dapat dikurangi (Machfud MD 2010).

Jika keadilan hanya dimaknai sebagai memberikan apa yang menjadi haknya, maka tidak ada satu orang pun yang boleh mengalami ketidakadilan sosial. Pemerintah dan masyarakat sama-sama berkewajiban mewujudkan keadilan sosial sesuai porsinya masing-masing, karena keadilan sosial merupakan kewajiban negara dan warga negaranya. Upaya mewujudkan keadilan sosial senantiasa mendahulukan kaum yang lemah ini harus ditolong selekasnya agar menjadi kuat. Mendahulukan dalam maknanya mengutamakan, bukan mengecualikan kelompok yang kuat (Gunawan 2015).

Upaya mewujudkan keadilan sosial senantiasa mendahulukan kaum yang lemah dan miskin, kaum yang lemah ini harus ditolong selekasnya agar menjadi kuat dan mempunyai kedudukan yang setara dengan golongan masyarakat lain, atau setidaknya ada upaya untuk merekatkan kesenjangan (gap) antara golongan yang kaya dengan golongan yang miskin dan terpinggirkan (marginal). Kaum miskin perlu dibela dan diberdayakan sebab tidak pernah dalam sejarah dunia kaum kaya dan berkuasa secara sukarela mau menyerahkan sebagian dari kekayaan dan kekuasaannya kepada yang miskin, sehingga tercapai keseimbangan yang adil. Keadilan sosial menghendaki keseimbangan antara kepentingan individu dan kepentingan bersama dalam masyarakat. Namun, perwujudan kesejahteraan bersama tidak boleh mengorbankan kepentingan individu (Gunawan

2015).

Keadilan adalah kebajikan utama dalam institusi sosial, sebagaimana kebenaran dalam sistem pemikiran. Suatu teori, betapapun elegan dan ekonomisnya, harus ditolak atau direvisi jika ia tidak benar; demikian juga hukum dan institusi, tidak peduli betapapun efisien dan rapinya. Setiap orang memiliki kehormatan yang berdasar pada keadilan sehingga seluruh masyarakat tidak dapat membatalkannya (Rawls 2011).

Kebenaran dan keadilan tidak dapat diganggu gugat, sebagai kebajikan utama umat manusia. Hak-hak yang dijamin oleh keadilan tidak tunduk pada tawar menawar politik dan kepentingan sosial. Perlu adanya keseimbangan, kesebandingan dan keselarasan (harmony) antara kepentingan pribadi dengan kepentingan masyarakat, termasuk di dalamnya negara. Keadilan merupakan nilai yang tidak dapat ditawar-tawar karena hanya dengan keadilan ada jaminan kestabilan dan ketentraman dalam hidup manusia.

Keadilan sebagai kesetaraan menyediakan pandangan yang jelas berbeda dari kaum utilitarian. Prinsip-prinsip keadilan diperoleh bukan dengan mengevaluasi kemanfaatan dari kecenderungan tindakan, melainkan dari pilihan rasional dari kondisi yang adil. Prinsip-prinsip tersebut dilekatkan pada struktur dasar masyarakat, bukannya setiap tindakan atau setiap tingkatan di mana keadilan dipersoalkan (Lebacqz 2013).

Bangsa Indonesia meyakini keadilan sosial merupakan manifestasi dari semua sila Pancasila, sehingga keadilan sosial secara

Ekonomi, Sosial, dan Budaya | 1435 
filosofis mempunyai makna sebagai berikut:

(1) Keadilan sosial merupakan amanat dari Tuhan yang harus dijunjung tinggi dalam penyelenggaraan pemerintahan di Indonesia.

(2) Keadilan sosial merupakan perwujudan dari watak dan sikap peradaban bangsa Indonesia.

(3) Keadilan sosial merupakan pilar utama untuk merekatkan persatuan dan kesatuan bangsa Indonesia, jika keadilan ini tidak dapat diwujudkan niscaya menjadi ancaman bagi persatuan dan kesatuan bangsa.

(4) Keadilan sosial merupakan nyawa (ruh) dalam penyelenggaraan pemerintahan yang demokratis, betapa runyamnya nasib bangsa ini jika pemilihan umum sebagai manifestasi demokrasi pancasila tidak diselenggarakan dengan jujur dan adil.

(5) Keadilan sosial merupakan tujuan sistem hukum bagi NKRI, karena keadilan sosial merupakan keadilan yang bersifat komunal, yang mengutamakan kepentingan umum di atas kepentingan individu maupun golongan. Dalam keadilan sosial sudah terkandung azas kepastian hukum yang sudah menjadi konsensus bersama bangsa Indonesia serta kebaikan umum (kemanfaatan) bagi seluruh rakyat Indonesia (Nuriyanto 2017).

Dalam strata sosial masyarakat di Indonesia dan juga di sebagian besar negara di dunia, ada masyarakat yang lemah dan ada pula yang kuat, baik dari sisi ekonomi, kedudukan sosial mapun tingkat pendidikannya. Seluruh strata sosial tersebut harus dilindungi hak-hak asasi dan kepentingannya, agar tujuan kesejahteraan bagi seluruh rakyat dapat diwujudkan oleh pemerintah. Kenyataan dalam praktik kehidupan bermasyarakat seringkali terjadi konflik kepentingan antara yang lemah dengan yang kuat, antara penguasa dan rakyatnya. Padahal di sisi lain, dalam penyelesaian perselisihan seringkali kemenangan hanya ditentukan oleh argumentasi-argumentasi hukum yang didasarkan pada rasionalisasi atas bukti-bukti, yang kuat argumentasinya pasti yang dimenangkan dan yang lemah tersingkirkan.
Mekanisme penyelesaian ini secara konvensional ditawarkan oleh lembaga peradilan, yang mengadopsi sistem hukum barat.

Padahal idealnya, dalam rangka penyelesaian sengketa yang dialaminya, para pencari keadilan (justiciabellen) berharap perkara yang mereka ajukan kepada hakim di pengadilan untuk diperiksa dan diadili, diputus dengan adil dan bijaksana serta tidak memihak kepada salah satu pihak yang berperkara. Adapun kenyataanya pengadilan adalah forum adu argumentasi hukum yang bertumpu pada kekuatan rasionalitas pembuktian untuk merebut keyakinan hakim yang dijadikan dasar dalam memutus perkara yang dihadapinya.

Para pencari keadilan tentu sangat mendambakan perkara-perkara yang diajukan ke pengadilan dapat diputus oleh hakim-hakim yang profesional dan memiliki integritas moral yang tinggi, sehingga setelah melalui proses pemeriksaan yang tidak memihak (imparsial) dan wajar dapat melahirkan putusan-putusan yang tidak saja mengandung aspek kepastian hukum semata, tetapi juga memberikan jaminan adanya keadilan. Karena keadilan itu yang "hukum" menjadi tujuan utama yang hendak dicapai dari proses penyelesaian sengketa di pengadilan.

Dalam menjalankan kewenangan ini khususnya pengujian Undang-Undang dan mengadili perselisihan hasil Pemilu, Mahkamah Konstitusi (MK) menegaskan diri tidak hanya bersandarkan legalitas formal Undang-Undang dalam mengadili, akan tetapi juga memiliki tanggung jawab mewujudkan tujuan norma hukum itu sendiri, yakni keadilan, kepastian dan kemanfaatan. Keadilan MK yang ingin dicapai tidak semata-mata sebuah keadilan prosedural, yakni keadilan sebagaimana sesuai rumusan bunyi UU, namun di sisi lain mengabaikan keadilan dan kepastian hukum.

Berdasarkan Perubahan Undang-Undang Dasar 1945 yang telah dilakukan MPR, ditegaskan bahwa kekuasaan kehakiman itu bertugas menegakkan hukum dan keadilan yang ditempatkan dalam posisi sama yang satu tidak lebih diutamakan dari yang lain. Pasal 24 ayat (1) Undang-Undang Dasar 1945 menyatakan kekuasaan kehakiman merupakan kekuasaan yang merdeka untuk menyelenggarakan

Ekonomi, Sosial, dan Budaya 1436 
peradilan guna menegakkandan "keadilan". Selain itu, Pasal 28D ayat (1) Undang-Undang Dasar 1945 juga menegaskan, setiap orang berhak atas pengakuan, jaminan, perlindungan, dan "kepastian hukum yang adil" (Tim 2009).

Di sebuah lembaga peradilan yang seharusnya memberikan keadilan, kepastian hukum yang ditawarkan undang-undang tidak jarang lebih diutamakan daripada keadilan. Undang-undang sendiri meski ditetapkan oleh pemerintah dan Dewan Perwakilan Rakyat dengan cara demokratis, tetapi belum tentu hasilnya mencerminkan nilai-nilai dari cita hukum dan keadilan. Pengalaman masa lalu membuktikan sebuah undang-undang tidak serta merta mencerminkan karakter yang responsif serta sesuai kepentingan rakyat dan menjadi cerminan nilai yang terkandung dalam cita-cita negara hukum yang demokratis. Prinsip penegakan keadilan dalam proses peradilan itu yang saat ini digali sedalam-dalamnya untuk merasakan keadilan substantif (substantive justice) di masyarakat dan tidak terbelenggu dengan keadilan yang ditetapkan undangundang (procedural justice).

Pendampingan hukum ini dilakukan
terhadap perkara pidana 270/Pid.B/2019/PN Lumajang dalam kasus tindak pidana pencurian dengan kekerasan, dengan Terdakwa Johan Andri, Edi Raharjo, Izroil Nurrohman, dan Ridi . Mereka berempat tergolong kelompok rentan karena mereka berpendidikan hanya Sekolah Dasar (SD), malahan Johan Andri tidak tamat SD dan sebenarnya mengalami gangguan psikologis karena pernah mangalami luka bakar di urat leher pada waktu kecil, tetapi karena tidak mampu memeriksakan diri ke dokter maka hakhanya sebagai orang dengan gangguan jiwa tidak terlindungi.

Padahal dari kronologis kasus, kasus ini berawal dari pengakuan Johan Andri yang tidak tahan ditekan oleh Saksi Suwagi dan petugas kepolisian yang langsung menuduhnya sebagai pelaku tindak pidana pencurian dengan kekerasan di rumah Tante Tiara majikannya sendiri, padahal petugas kepolisian tidak mempunyai bukti yang cukup untuk melakukan penyidikan.

\section{Pengabaian Hak Hukum Karena Merasa Tidak Bersalah}

Salah satu masalah yang terjadi dalam sistem peradilan pidana adalah terjadinya pelanggaran hak pada salah satu atau seluruh tingkat pemeriksaan. Pelanggaran tersebut dapat berupa pelanggaran prosedural, pelanggaran adminstratif, pelanggaran terhadap diri pribadi tersangka sampai pada pelanggaran berat seperti rekayasa saksi-saksi dan rekayasa bukti-bukti suatu perkara.

Apabila suatu keterangan tersangka yang diduga telah melakukan tindak pidana dipergunakan sebagai alat bukti bagi penyidik ternyata perolehannya atas dasar tekanan atau paksaan yang berakibat penderitaan secara psikis dan fisik dan menimbulkan rasa takut. Perolehan keterangan sebagai alat bukti tersebut harus dinyatakan tidak sah karena bisa berisi suatu pengakuan yang terekayasa. Kesalahan prosedur dan kesalahan penyidikan dapat mengakibatkan kesalahan dalam menentukan pelaku tindak pidana atau sering disebut dengan salah tangkap (Purwoleksno 2010).

Dalam naskah pembelaan (Pleidoi) Tim LKBH yang dibacakan di muka pengadilan disampaikan hal hal sebagai berikut :

Bahwa penangkapan ke-empat terdakwa (Johan Andri, Edi Rahardjo, Izroil Nurrohman dan Ridi) berdasarkan fakta-fakta persidangan adalah sangat lemah dan terkesan asal tangkap. Karena Aparat Kepolisian Sektor Gucialit tidak melakukan proses penyelidikan dan proses penyidikan yang secara tegas sudah diatur didalam KUHAP serta peraturan perundangundangan yang lain. Hal ini dapat terlihat berdasarkan fakta persidangan bahwa sesungguhnya aktor penting dalam kasus ini penangkapan adalah saudara Suwagi. Karena atas keterangan Suwagi ke-empat Tersangka dalam kasus ini ditangkap oleh anggota Kepolisian Sektor Gucialit, hal ini juga didukung bukti percakapan via aplikasi Whatsapp Messenger antara saudara Doni (Terdakwa dalam kasus lain) dengan Tiananto atau Tante Tiara (saksi korban) bahwa Suwagi yang Ekonomi, Sosial, dan Budaya | 1437 
menjebloskan ke-empat Terdakwa ditambah 2 (dua) orang Tersangka dalam kasus lain. Kondisi ini diperkuat dengan adanya permintaan saksi korban agar para tersangka dibebaskan dari tuntutan hukum . Sungguh ironis, bahwa Penangkapan terhadap seorang pelaku tindak kejahatan hanya didasarkan pada keterangan seorang saksi semata, bukan penangkapan yang dilakukan dari hasil sebuah proses penyelidikan dan penyidikan yang dilakukan oleh petugas kepolisian Sektor Gucialit selaku penyidik.

Bahwa dalam perkara ini telah diajukan Para Terdakwa ke persidangan yaitu yang bernama Johan Andri, Edi Raharjo, Izroil Nurrohman, dan Ridi, yang identitasnya lengkap sesuai dengan Surat Dakwaan, tetapi bukti yang mendukung mereka Para Terdakwa sebagai pelaku tindak pidana yang dikdakwakan sama sekali tidak terbukti secara sah dan meyakinkan. Karena satu-stunya Saksi dalam perkara ini hanya Saksi Tiananto alias Tante Tiara yang mengalami sendiri, melihat dan mendengar sendiri. Sedangkan saksi Yuliani tidak mengetahui kejadian tersebut. Apalagi Saksi Suwagi, yang hanya mendengar dari pengakuan Johan, merupakan Saksi yang tidak melihat sendiri, tidak mendengar sendiri dan tidak mengalami sendiri (testimonium de auditu). Sehingga yang terungkap dalam perkara ini saksi satu-satunya adalah Tiananto alias Tante Tiara, maka pembuktian perkara ini berlaku asas ullus testis nullus testis (satu saksi bukanlah saksi).

\section{Koordinasi Antar Penegak Hukum Di Daerah Yang Mengabaikan Hak-Hak Terdakwa}

Pada umumnya langkah pertama dalam pelaksanaan pendampingan hukum dalam perkara pidana dengan nomor perkara 270/Pid.B/2019/PN.Lmj adalah sejak pemanggilan dan pemeriksaan oleh penyidik di Kepolisian, tetapi dalam perkara ini Penasihat Hukum baru dihubungi setelah Berkas Acara Pemeriksaan (BAP) yang dibuat oleh Penydidik sudah lengkap dan terkesan prosesnya dipercepat untuk menuju persidangan di Pengadilan Negeri Lumajang.

Sidang perdana dalam kasus ini dilaksanakan pada tanggal 3 Desember 2019. Dalam sidang perdana ini keempat terdakwa tidak didampingi oleh kuasa hukum dari LKBHUWP. Hal ini dikarenakan lemahnya koordinasi antara aparat penegak hukum yang menangani perkara ini, sehingga pemberitahuan sidang tidak diterima oleh Tim LKBH-UWP sehingga hak-hak Terdakwa untuk menghubungi Penasihat Hukum dan mendapatkan pendampingan hukum dengan sengaja diabaikan.

Dalam putusan perkara ini Majelis Hakim yang memeriksa dan mengadili Terdakwa hanya memutus berdasarkan keterangan saksi penyidik kepolisian, padahal Mahkamah Agung mempunyai pendapat tersendiri dalam menilai pembuktian terhadap keterangan saksi penyidik. Dalam Putusan Mahkamah Agung Nomor 1531/K/Pid.Sus/2010 menyatakan bahwa pihak kepolisian dalam pemeriksaan perkara a quo mempunyai kepentingan terhadap perkara agar perkara yang ditanganinya terbukti secara meyakinkan di pengadilan, sehingga keterangannya pasti memberatkan atau menyudutkan terdakwa, oleh karena itu penyidik kepolisian mungkin saja merekayasa keterangannya sendiri (Ali 2019). Hal ini menyimpang dari penjelasan pasal 185 ayat (6) KUHAP yang menyatakan bahwa saksi adalah orang yang benar-benar diberikan secara bebas, netral, objektif dan jujur (vide Penjelasan Pasal 185 ayat (6) KUHAP). Artinya Polisi yang melakukan penangkapan, penyelidikan dan penyidikan tidak dapat dihadirkan ke persidangan untuk memberikan keterangan sebagai saksi karena posisinya yang sarat akan kepentingan. Namun, kehadiran polisi penyelidik ataupun penyidik masih bisa dihadirkan asalkan sebagai saksi verbal lisan sebagaimana diakui oleh Mahkamah Agung.

Dalam kasus ini, terdapat 3 (tiga) orang saksi penyidik yang dihadirkan dalam persidangan yang seharusnya keterangan yang disampaikan oleh saksi penyidik tidak dapat dipertimbangkan sebagai Saksi jika mendasarkan pada yurisprudensi Mahkamah Agung di atas. Meskipun keterangan mereka Ekonomi, Sosial, dan Budaya 1438 
dihadirkan di persidangan, tetapi jika melihat isi kesaksian dari para saksi Penyidik, tidak ada satupun dari mereka yang melihat, mendengar

dan mengalami peristiwa pencurian sebenarnya. Sehingga dari hal ini bisa terlihat bahwa Penuntut Umum kurang mampu menghadirkan saksi-saksi yang mempunyai nilai alat bukti yang kuat dalam pembuktian.

Dalam perkara ini, ketika Jaksa peneliti mendapatkan berkas dari pihak penyidik, seharusnya tidak segera menyatakan berkas perkara ini sudah lengkap karena dari Saksi yang diajukan pihak penyidik tidak mempunyai kekuatan sebagai alat bukti. Apalagi melihat keterangan dari penyidik tidak ada satupun yang melihat, mendengar atau merasakan langsung peristiwa pembunuhan yang terjadi, seharusnya Jaksa peneliti tetap menyatakan bahwa berkas perkara yang diajukan belum lengkap dan harus dilengkapi kembali oleh pihak penyidik. Saksi yang dihadirkan oleh JPU dalam pemeriksaan perkara ini kebanyakan dari pihak penyidik. Padahal ketentuan tersebut tidak sesuai dengan isi dari Putusan Mahkamah Agung Nomor 1531/K/Pid.Sus/2010.

Dalam putusan tersebut disebutkan bahwa kedudukan dari kepolisian sebagai saksi mempunyai konflik kepentingan, sehingga keterangannya pasti akan memberatkan atau menyudutkan bahwa bisa merekayasa keterangan. Padahal yang dibutuhkan sebagai saksi adalah orang yang benar-benar diberikan secara bebas, netral, objektif dan jujur.

\section{SIMPULAN DAN SARAN}

Berdasarkan pendampingan hukum dan bantuan hukum yang dilaksanakan dalam perkara pidana dengan Nomor Perkara : 270/Pid.B/2019/PN Lmj, dapat ditarik kesimpulan bahwa dalam penanganan perkara pidana khususnya yang melibatkan kelompok rentan hendaknya aparat penegak hukum tetap menjalankan proses hukum sesuai dengan hukum acara yang berlaku tanpa membedakan status sosial tersangka atau terdakwa.

Berkurangnya masa hukuman para terdakwa selama 1 tahun penjara dari tuntutan jaksa penuntut umum pada dasarnya jauh dari harapan para terdakwa dan Tim LKBH-UWP yang memohon kepada Majelis Hakim berdasarkan fakta fakta persidangan Majelis Hakim membebaskan para terdakwa dari segala tuntutan Jaksa Penuntut Umum.

Sehubungan dengan kesimpulan ini maka bagi pemerintah diharapkan lebih menggalakkan lagi upaya sosialisasi hak-hak hukum dan perlindungan hak asasi manusia kepada kelompok rentan. Di sisi lain pemerintah juga harus memberikan akses, baik informasi maupun layanan kepada masyarakat rentan, khususnya yang sedang menghadapi kasus-kasus hukum.

\section{DAFTAR REFERENSI}

Afifah, Wiwik. 2020. "Bantuan Hukum Kelompok Rentan.” 16(11):123-38.

Ali, Dahlan. 2019. "Kedudukan Kesaksian Polisi Penangkap Dalam Pemeriksaan Perkara Tindak Pidana Penyalahgunaan Narkoba.” 3(April):114-28.

Gunawan, Yopi dan Kristian. 2015. Perkembangan Konsep Negara Hukum Dan Negara Hukum Pancasila. Bandung: Refika Aditama.

Hadi, Ilman. 2012. “"Miranda Rules' Dalam Hukum Acara Pidana Indonesia." Hukum Online. Retrieved September 9, 2021 (https://www.hukumonline.com/klinik/det ail/ulasan/1t5023471f2316e/pelanggaranmiranda-rule).

Larson, Aaron. 2018. "What Is Habeas

Corpus." Expert Law. Retrieved

September 9, 2021

(https://www.expertlaw.com/library/crimi nal/habeas_corpus.html).

Lebacqz, Karen. 2013. Teori-Teori Keadilan; Analisis Kritis Terhadap Pemikiran JS.Mill, John Rawls, Robert Nozick, Reinhold Neibuhr, Jose Porfirio Miranda. Bandung: Nusa Media.

Machfud MD. 2010. Perdebatan Hukum Tata Negara Pasca Amandemen Konstitusi. Jakarta: Rajawali Pers.

Ekonomi, Sosial, dan Budaya 1439 
Nurhayati, Ratna. 2021. "The Application of Presumption of Innocence as the Protection of Human Rights of Suspect or Defendant in Preventing Miscarriage of Justice in the Indonesian Criminal Justice System." Systematic Reviews in Pharmacy 12(3):126-29.

Nuriyanto. 2017. "Kekuatan Hukum Rekomendasi Ombudsman Dalam Penyelesaian Maladministrasi Pelayanan Publik." Universitas 17 Agustus 1945 Surabaya.

Prasetyo, Teguh. 2015. Keadilan Bermartabat Perspektif Teori Hukum. Bandung: Nusa Media.

Purwoleksno, Didik Endro. 2010. Laporan Akhir Naskah Akademis Rancangan Undang-Undang Tentang Hukum Acara Pidana. Jakarta.

Rawls, John. 2011. Teori Keadilan: DasarDasar Filsafat Politik Untuk Mewujudkan Kesejahteraan Sosial Dalam Negara. Yogjakarta: Pustaka Pelajar.

Rukmini, Mien. 2003. Perlindungan HAM Melalui Asas Praduga Tidak Bersalah
Dan Asas Persamaan Dalam Hukum Pada Sistem Peradilan Pidana Di Indonesia. Bandung: Alumni.

Sugiyarto. 2019. "Korban Perampokan Di

Lumajang Malah Menangis Dan Sujud Di

Kaki Kapolres Minta Perampoknya

Dibebaskan Artikel Ini Telah Tayang Di

Tribunnews.Com Dengan Judul Korban

Perampokan Di Lumajang Malah

Menangis Dan Sujud Di Kaki Kapolres

Minta Perampoknya Dibebask."

TribunNews. Com, October 20.

Tim. 2009. Mengawal Demokrasi, Menegakkan Keadilan Substantif; Refleksi Kinerja MK 2009 Proyeksi 2010. Jakarta: Mahkamah Konstitusi Republik Indonesia.

Tobias, Marc Weber and R. David Petersen. n.d. Pre-Trial Criminal Procedure A Survey on Constitusional Right. Charles C. Thomas Publisher. 